УДК 796.032(100) : 316.421

DOI https://doi.org/10.26661/2663-5925-2021-3-05

\title{
РОЗВИТОК СПОРТИВНИХ ІГОР У ТЕРИТОРІАЛЬНИХ ГРОМАДАХ ІВАНО-ФРАНКІВСЬКОЇ ОБЛАСТІ: ПЕРСПЕКТИВИ ДОСЛІДЖЕНЬ
}

\author{
Лисейко К. \\ аспірант кафедри спортивно-педагогічних дисцииллін \\ ДВНЗ «Прикарпатський національний університет імені Василя Стефаника» \\ вул. Шевченка, 57, Івано-Франківськ, Украӥна \\ orcid.org/0000-0001-7776-2714 \\ tlum_vms@meta.ua \\ Яців Я. М. \\ кандидат педагогічних наук, \\ професор кафедри спортивно-педагогічних дисичилін \\ ДВНЗ «Прикарпатський національний університет імені Василя Стефаника» \\ вул. Шевченка, 57, Івано-Франківськ, Украӥна \\ orcid.org/0000-0003-2474-040 \\ yaroslav.yatsiv@pnu.edu.ua
}

Ключові слова: управління, громада, спортивні ігри, розвиток, перспективи, дослідження.
Ефективний розвиток фізичної культури та спорту передусім відбувається за рахунок беззаперечного розуміння дуже важливої ролі фізичної культури та спорту в розвитку громади. Тому зміни в управлінні та перехід до децентралізованих механізмів позначається на всіх сферах діяльності, зокрема фізичній культурі та спорті. Мета - з'ясувати перспективу наукового пошуку в напрямі розвитку спортивних ігор в умовах децентралізації влади (на прикладі об'єднаних територіальних громад Івано-Франківської області). Для цього використано теоретичний аналіз та узагальнення, аналіз документальних матеріалів. Установлено можливість розв'язання актуального науково-практичного завдання щодо розвитку спортивних ігор на теренах Івано-Франківської області в умовах децентралізації влади. Послідовними кроками цього виступають такі завдання: визначити сутність, передумови формування та особливості розвитку спорту загалом та окремих видів спорту на різних рівнях управління сферою фізичної культури і спорту; визначити структуру та зміст нормативно-правового та програмнонормативного підгрунтя діяльності суб'єктів 3 розвитку спортивних ігор на місцевому рівні; встановити динаміку основних показників розвитку спортивних ігор за різних форм організації управління фізичною культурою та спортом в Івано-Франківській області та обгрунтувати програму розвитку спортивних ігор у територіальних громадах Івано-Франківської області. У межах виконання дослідження виявлено протиріччя між соціально-економічними змінами в Україні, децентралізацією повноважень 3 підвищенням повноважень органів місцевого самоврядування (об'єднаних територіальних громад) i необхідністю формування здорової громади, популяризації засобів фізичної культури і спорту серед населення шляхом сталого підтримання механізмів розвитку масових та популярних видів спорту, зокрема спортивних ігор. Розв’язання цього протиріччя передбачає планування та реалізацію окремого наукового дослідження 3 відповідним формуванням методологічного, організаційного та наукового апарату. 


\title{
DEVELOPMENT OF SPORTS GAMES IN TERRITORIAL COMMUNITIES OF IVANO-FRANKIVSK REGION: RESEARCH
}

\author{
Lyseiko K. \\ Postgraduate Student at the Department of Sports and Pedagogical Disciplines \\ Vasyl Stefanyk Precarpathian National University \\ Shevchenko str., 57, Ivano-Frankivsk, Ukraine \\ tlum_vms@meta.ua
}

Yatsiv Ya. M.

Candidate of Pedagogical Sciences, Professor at the Department of Sports and Pedagogical Disciplines

Vasyl Stefanyk Precarpathian National University

Shevchenko str., 57, Ivano-Frankivsk, Ukraine

yaroslav.yatsiv@pnu.edu.ua

Key words: management, community, sports games, development, prospects, research.
The effective development of physical culture and sports is primarily take place due to an unquestionable understanding of the important role of physical culture and sports in community development. Therefore, changes in governance and the transition to decentralized mechanisms affect all areas of activity, including physical culture and sports. Purpose to find out the prospects of scientific research in the direction of the development of sports games in the context of decentralization of power (on the example of the united territorial communities of Ivano-Frankivsk region). There are used theoretical analysis and generalizations, analysis of documentary materials. It has been established the possibility of solving the actual scientific and practical problem of the development of sports games in the Ivano-Frankivsk region in the conditions of decentralization of power. The following tasks are successive steps: to determine the essence, prerequisites for the formation and features of the development of sports in general and separate sports at different levels of management in the field of physical culture and sports; to determine the structure and content of the normative and legal, program and normative basis of the activity of subjects for the development of sports games at the local level; to establish the dynamics of the main indicators of the development of sports games in various forms of management of physical culture and sports in Ivano-Frankivsk region and to substantiate the program of sports games development in the territorial communities of Ivano-Frankivsk region. The study revealed a contradiction between social and economic changes in Ukraine, decentralization of powers with increasing powers of local governments (united territorial communities) and the need to form a healthy community, promotion of physical culture and sports among the population through sustainable maintenance of mechanisms for the development of mass and popular sports, including sports games. The solution of this contradiction involves the planning and implementation of a separate scientific study with the appropriate formation of methodological, organizational, scientific apparatus.
Постановка проблеми та аналіз основних досліджень. На сучасному етапі розвитку демократичної правової держави важливу роль відіграє запровадження реформ. За останній період часу вони в Україні пов'язані з децентралізацією влади $[1 ; 3 ; 5 ; 6]$. Сутність цього процесу полягає в утвердженні демократичного управління, передачі владних повноважень територіальним громадам, забезпеченні широкої участі громадян в управлінні справами загалом за різними видами діяльності та у фізичній культурі й спорті зокрема $[7 ; 9 ; 15 ; 17]$.

Наукова проблема децентралізації в різних сферах діяльності суспільства сьогодні є надзвичайно актуальною. Широкого обговорення зазна- 
чена проблематика отримала в колі науковців, експертів і громадськості. Відповідно, це потребує свого відображення в науковому обгрунтуванні відповідних аспектів галузі фізичної культури і спорту $[4 ; 10 ; 18]$.

Децентралізація передбачає такий спосіб розмежування та визначення завдань i функцій, за якого більшість із них переходить від рівня центральних органів до нижчого рівня і стає власними завданнями та повноваженнями органів власне нижчого управлінського рівня [4; 6; 9].

Беззаперечно те, що децентралізація є однією 3 форм усталення демократії, що дає змогу зберегти єдність держави та iї інститутів.

Розширення місцевого самоврядування, активізація населення щодо забезпечення власних потреб та інтересів, звуження сфери впливу держави на суспільство відбувається завдяки впливу механізмів саморегуляції, виробленим самим суспільством, зменшенням витрат держави й платників податків на утримання держапарату $[1 ; 6 ; 15]$.

Окремі дослідники наголошують, що держава, віддаючи повноваження місцевим органам управління, не втрачає свого центрального значення, а навпаки, отримує можливості вибудовування більш стрункого й ефективного організму соціального управління $[5 ; 15 ; 17 ; 18]$. Саме на місцевому рівні, де у людей є можливість безпосередньо впливати на прийняття рішень, що поліпшують їхне життя, теоретичні основи демократії наповнюються практичним змістом, і це надає відчутний імпульс розвитку демократичних процесів у всьому суспільстві $[1 ; 3 ; 6 ; 15 ; 17]$.

Проведений аналіз вказує, що ефективний розвиток фізичної культури та спорту передусім відбувається за рахунок беззаперечного розуміння дуже важливої ролі фізичної культури та спорту в розвитку громади.

Мета дослідження - з'ясувати перспективу наукового пошуку в напрямі розвитку спортивних ігор в умовах децентралізації влади (на прикладі об'єднаних територіальних громад Івано-Франківської області).

Матеріал і методи. Використано теоретичний аналіз та узагальнення (вивчення змісту наукової та методичної літератури для встановлення рівня вивченості проблеми дослідження, 3'ясування основних аспектів розвитку спортивних ігор на місцевому рівні); аналіз документальних матеріалів (вивчення змісту нормативно-правових документів національного, регіонального та місцевого рівнів, установчих документів спортивних федерацій, клубів, звітних документів 3 розвитку фізичної культури і спорту, зокрема, спортивних ігор на теренах Івано-Франківської області).

Результати дослідження та їх обговорення. В Україні процеси децентралізації розпочато
2014 року і сьогодні вони чинять грунтовний вплив на різні сфери життя громад. В основу нормативно-правового регулювання покладено Концепцію реформи місцевого самоврядування та територіальної організації влади, Законів «Про співробітництво територіальних громад», «Про добровільне об'єднання територіальних громад» тощо $[3 ; 5 ; 6 ; 7]$.

Процеси децентралізації стосуються всіх сфер діяльності та визначають важливість участі в їх регулюванні об'єднаних територіальних громад на місцевому рівні. Сфера фізичної культури $\mathrm{i}$ спорту є невід'ємною частиною здоров'язбережувального компоненту громади, формування та збереження пріоритетів гармонійного розвитку населення різних вікових та інших соціальних груп, підвищення спортивних результатів та підвищення залученості різних груп населення до активного дозвілля й занять фізичною культурою і спортом тощо $[1 ; 4 ; 8 ; 10 ; 15]$.

Багатьма фахівцями підтверджено участь мешканців села чи міста в реалізації прав на різні напрями соціальної діяльності, зокрема фізичної культури і спорту. Відповідна громада може впливати на якість цих послуг лише тоді, коли відповідальність за їх надання залежить значною мірою від них самих. Найближчим до людей рівнем влади $€$ органи місцевого самоврядування. Саме вони нині мають широкі повноваження і ресурси, можливості вирішувати зазначені питання на місцевому рівні та нести за це відповідальність $[3 ; 17 ; 18 ; 19]$.

Загальноприйнятним $\epsilon$ твердження про популярність фізичної культури і спорту серед населення. Фахівцями визначається, що пріоритети за чисельністю занять, психоемоційною сприятливістю покладені на спортивні ігри. Найбільш популярним та затребуваним видом спорту, за твердженням практиків, є футбол $[11 ; 12]$. Проте в регіональному та місцевому контексті не варто забувати й про інші популярні спортивні ігри (баскетбол, волейбол, настільний теніс, футзал та інші) $[2 ; 13 ; 14 ; 16]$.

За допомогою перегляду підходів до забезпечення діяльності громади змінилася мера їх залучення до розвитку спортивних ігор. В Україні створено адміністративні центри, які сьогодні самостійно визначають напрями та особливості розвитку найбільш популярної та масової групи видів спорту, а саме спортивних ігор. В Івано-Франківській області, що налічує понад 1,368 тис. населення, створено 62 територіальні громади в шести районах області. Це ставить підвищені вимоги до організаційного, методичного та інших складників забезпечення діяльності сфери фізичної культури і спорту.

Таким чином, виявлено протиріччя між соціально-економічними змінами в Україні, децен- 
тралізацією повноважень 3 підвищенням повноважень органів місцевого самоврядування (об'єднаних територіальних громад) й необхідністю формування здорової громади, популяризації засобів фізичної культури і спорту серед населення шляхом сталого підтримання механізмів розвитку масових та популярних видів спорту, зокрема спортивних ігор.

Його розв'язання можна вбачати в з'ясуванні передумов становлення та обгрунтування програми розвитку спортивних ігор на теренах Івано-Франківської області в умовах децентралізації влади.

Послідовними кроками цього виступають такі завдання:

- визначити сутність, передумови формування та особливості розвитку спорту загалом та окремих видів спорту на різних рівнях управління сферою фізичної культури і спорту;

- визначити структуру i зміст нормативно-правового та програмно-нормативного підгрунтя діяльності суб' єктів з розвитку спортивних ігор на місцевому рівні (на прикладі Івано-Франківської області);

- встановити динаміку основних показників розвитку спортивних ігор за різних форм організації управління фізичною культурою та спортом в Івано-Франківській області;

- обгрунтувати програму розвитку спортивних ігор в об'єднаних територіальних громадах Івано-Франківської області та оцінити їі прогностичну ефективність.

Об’єктна сфера дослідження обмежується науковими питаннями розвитку спорту в умовах децентралізації влади в Україні. При цьому предметною сферою дослідження можна визначити розвиток спортивних ігор в об'єднаних територіальних громадах Івано-Франківської області.

Для реалізації конкретного наукового дослідження в зазначеному напрямі ми пропонуємо використати такі методи дослідження: теоретичний аналіз та узагальнення (для вивчення змісту наукової та методичної літератури, даних мережі Інтернет для встановлення рівня вивченості проблеми дослідження, 3'ясування основних аспектів розвитку спортивних ігор на місцевому рівні); аналіз документальних матеріалів (для вивчення змісту нормативно-правових документів національного, регіонального та місцевого рівнів, установчих документів спортивних федерацій, клубів, звітних документів з розвитку фізичної культури i спорту, зокрема спортивних ігор на теренах Івано-Франківської області); соціологічне опитування (для уточнення проблемного поля та з'ясування рекомендацій суб'єктів діяльності щодо розвитку спортивних ігор в ОТГ Івано-Франківської області); метод експертного оцінювання (для визначення пріоритетності напрямів та конкретизованих механізмів плану розвитку спортивних ігор в ОТГ Івано-Франківської області); методи математичної статистики (для оброблення емпіричних даних на різних етапах дослідження).

Отримані в ході дослідження результати можуть передбачати таке:

- обгрунтування плану розвитку спортивних ігор на місцевому рівні, що передбачатиме розроблення конкретизованих напрямів i їхнє оцінювання для об'єднаних територіальних громад Івано-Франківської області;

- визначення структури та змісту діяльності громадських і державних структур фізичної культури і спорту, зокрема, в напрямі реалізації політики та розвитку спортивних ігор в умовах децентралізації влади в Україні (на прикладі Івано-Франківської області);

- пошук відомостей про основні показники розвитку спортивних ігор на теренах Івано-Франківської області за різних форм організації управління фізичною культурою та спортом;

- удосконалення наукових даних про структуру та зміст нормативно-правового та програмно-нормативного забезпечення діяльності міських та обласних спортивних федерацій, громадських організацій, спортивних клубів у напрямі розвитку спортивних ігор;

- пошук відомостей про сутність, передумови та особливості впливу чинників об'єктивного та суб'єктивного характеру на розвиток спортивних ігор на теренах Івано-Франківської області за різних форм організації управління фізичною культурою та спортом.

Організація дослідження може передбачати низку послідовних етапів. Передбачаємо, що на першому етапі буде проведено пошук і вивчення літератури, публікацій та наукових досліджень за проблематикою дослідження; буде конкретизовано тему, визначено мету та завдання, об'єкт та предмет дослідження, проведено добір методів згідно зі сформульованими завданнями. Другий етап передбачатиме вивчення показників фізкультурної та спортивної діяльності зі спортивних ігор в об'єднаних територіальних громадах Івано-Франківської області, вивчення змісту нормативно-правових та програмно-нормативних документів, що регламентують фізкультурно-спортивну та оздоровчу діяльність на місцевому, регіональному та загальнонаціональному рівні. Третій етап буде спрямований на вивчення та зіставлення показників розвитку спортивних ігор на території Івано-Франківської області, виявлення та оцінку чинників впливу на розвиток спортивних ігор в об'єднаних територіальних громадах (на прикладі Івано-Франківської області), розроблення та експертне оцінювання плану роз- 
витку спортивних ігор в ОТГ Івано-Франківської області, опрацювання та опис наукових результатів. Заключний, четвертий етап буде передбачати аналіз та узагальнення результатів дослідження та зіставлення їх з наявними даними наукової та методичної літератури, впровадження результатів у практику.

При цьому практичне значення роботи полягатиме в теоретичному та емпіричному обгрунтуванні програми (плану) розвитку спортивних ігор 3 урахуванням чинників соціально-економічного розвитку країни на місцевому рівні, в розробленні та експертній перевірці напрямів розвитку спортивних ігор в умовах децентралізації влади (на прикладі Івано-Франківської області); з'ясуванні особливостей діяльності організаційних структур Івано-Франківщини (державного та громадського підпорядкування) 3 розвитку спортивних ігор.
Висновки. У межах виконання дослідження виявлено протиріччя між соціально-економічними змінами в Україні, децентралізацією повноважень 3 підвищенням повноважень органів місцевого самоврядування (об'єднаних територіальних громад) й необхідністю формування здорової громади, популяризації засобів фізичної культури і спорту серед населення шляхом сталого підтримання механізмів розвитку масових та популярних видів спорту, зокрема спортивних ігор. Розв'язання цього протиріччя передбачає планування та реалізацію окремого наукового дослідження з відповідним формуванням методологічного, організаційного, наукового апарату.

Перспективи подальших досліджень передбачають обговорення та затвердження індивідуального плану виконання дослідження, пошуку наукової та науково-методичної інформації для реалізації окремих етапів дослідження.

\section{ЛІТЕРАТУРА}

1. Базенко В.А. Свропейський досвід управління розвитком фізичної культури та спорту на місцевому рівні. Ефективність державного управління. 2017. Вип. 1. С. 156-166.

2. Булатова М.М., Бубка С.Н., Платонов В.Н. Олимпийские игры (1976-2012). Киев : Олимп. лит., 2012. Том $2.512 \mathrm{c}$.

3. Гамбург Л.С. Теоретичні питання децентралізації державної влади в системі публічної влади унітарної держави. Вісник Запорізького національного університету. 2014. № 4 (I). C. 134-145.

4. Гасюк І.Л. Державне управління фізичною культурою та спортом: стан та перспективи розвитку : моногр. Харків : ПП Балюк І.Б., 2011. 432 с.

5. Гладка T.I. Децентралізація влади в Україні як засіб посилення демократії та підвищення ії стабільності. Державне управління: удосконалення та розвиток. 2015. 12.

6. Гройсман В. Процеси централізації та децентралізації в сучасному державному управлінні. Державне управління та місиеве самоврядування. 2015. Вип. 2. С. 26-37.

7. Данилишин Б. Як децентралізувати управління в Україні. Економічна правда. 2015. 13 липня. URL: http://www.epravda.com.ua/columns/2015/07/13/550472/

8. Жданова О.М., Чеховська Л.Я. Управління сферою фізичного виховання і спорту : навч. посіб. Дрогобич : Коло, 2009. 224 с.

9. Кузьменко О. Сучасний стан державного управління фізичною культурою й спортом в Україні та Свропі. Держава та регіони. Серія: Державне управління. 2011. № 3. С. 36-41.

10. Мічуда Ю.П., Огньов Ю.М. Особливості розробки інвестиційних проектів з розвитку сучасної матеріальної інфраструктури українського спорту. Стратегічне управління розвитком фізичної культури і спорту в контексті 25-річчя незалежності України : Зб. матеріалів IV Регіон. наук.практ. інтер.-конф. з міжнар. участю. Харків : ХДАФК, 2016, С. 16-21.

11. Николаенко В.В., Шевченко А.Ю., Булавинец В.А. Сравнительный анализ организации детско-юношеских соревнований по футболу в Украине и странах западной Европы. Науковий часопис НПУ імені МП Драгоманова. Серія 15: Науково-педагогічні проблеми фізичної культури (фізична кульmypa i cnopm). 2017. № 6. С. 44-48.

12. Павелко А.В. Організаційно-правові засади державного управління системою безпеки на футбольних заходах. Державне будівництво. 2009. № 1. С. 53-67.

13. Петрушевський С.І. Розвиток гандболу в Україні в умовах глобалізації спорту : дис. ... д-ра філософії : 017. Київ, 2021. 226 с.

14. Платонов В., Есентаев Т. Организационно-управленческие модели подготовки спортсменов высокой квалификации в условиях политизации и коммерциализации олимпийского спорта. Наука в олимпийском спорте. 2015. № 2. С. 19-26.

15. Путятіна Г. Інституційне забезпечення участі громади в розвитку сфери фізичної культури та спорту. Молодіжний науковий вісник Східноєвроп. наи. ун-ту імені Лесі Украйнки. Серія: Фізичне виховання i спорт. 2015. Вип. 19. С. 27-31. 
16. Сушко Р.О. Теоретико-методичні основи розвитку спортивних ігор в умовах глобалізації (на матеріалі баскетболу) : автореф. Київ, 2018. 43 с.

17. Черба В.М., Герасимова С.В. Стан та перспективи розвитку сфери фізичної культури в Україні. Економіка та держава. 2017. № 7. С. 70-75.

18. Шевчук I.B. Механізми державного управління у сфері фізичної культури і спорту на регіональному рівні : автореферат. Київ : Академія муніципального управління, 2015. 23 с.

19. Шкребтій Ю.М. Стан та напрями удосконалення системи фізичного виховання молоді. Спортивний вісник Придніпров'я. 2005. № 1. С. 13-16.

\section{REFERENCES}

1. Bazenko V. A. (2017) Yevropeyskiy dosvid upravlinnya rozvitkom fizichnoi kulturi ta sportu na mistsevomu rivni [European management experience develops physical culture and sports at the local level]. Efektivnist derzhavnoho upravlinnya. vol. 1, pp. 156-166. (in Ukrainian)

2. Bulatova M. M., Bubka S.N., Platonov V.N. (2012) Olimpiyskie ihry (1976-2012) [Olympic Games (1976-2012)]. Kyiv: Olimpiyska literature. (in Russian)

3. Hamburh L. S. (2014) Teoretichni pitannya detsentralizatsiyi derzhavnoi vladi v sistemi publichnoi vladi unitarnoi derzhavi [Theoretical issues of decentralization of state power in the system of public power of a unitary state]. Visnik Zaporizkoho natsionalnoho universitetu. 2014. no. 4 (I). pp. 134-145. (in Ukrainian)

4. Hasyuk I.L. (2011) Derzhavne upravlinnya fizichnoyu kulturoyu ta sportom: stan ta perspektivi rozvitku [State management of physical culture and sports: state and prospects of development] : monohr. Kharkiv : PP Balyuk I. B., 432 p. (in Ukrainian)

5. Hladka T.I. (2015) Detsentralizatsiya vladi v Ukraini yak zasib posilennya demokratiyi ta pidvishchennya yiyi stabilnosti [Decentralization of power in Ukraine as a means of strengthening democracy and increasing its stability]. Derzhavne upravlinnya: udoskonalennya ta rozvitok. no. 12. (in Ukrainian)

6. Hroysman V. (2015) Protsesi tsentralizatsiyi ta detsentralizatsiyi v suchasnomu derzhavnomu upravlinni [Processes of centralization and decentralization in modern public administration]. Derzhavne upravlinnya ta mistseve samovryaduvannya, vol. 2, pp. 26-37. (in Ukrainian)

7. Danilishin B. (2015) Yak detsentralizuvati upravlinnya $v$ Ukraini [How to decentralize management in Ukraine] [Elektronniy resurs] Ekonomichna pravda. 13 lipnya. Retrieved from: http://www.epravda.com. ua/columns/2015/07/13/550472/ (22.09.2021) (in Ukrainian)

8. Zhdanova O.M., Chekhovska L.Ya. (2009) Upravlinnya sferoyu fizichnoho vikhovannya i sportu [Management of physical education and sports:]: navch. posib. Drohobich: Kolo. 224 p. (in Ukrainian)

9. Kuzmenko O. (2011) Suchasniy stan derzhavnoho upravlinnya fizichnoyu kulturoyu y sportom v Ukraini ta Yevropi [The current state of public administration of physical culture and sports in Ukraine and Europe]. Derzhava ta rehioni. Seriya: Derzhavne upravlinnya. no. 3, pp. 36-41. (in Ukrainian)

10. Michuda Yu.P., Ohnov Yu.M. (2016) Osoblivosti rozrobki investitsiynikh proektiv z rozvitku suchasnoi materialnoi infrastrukturi ukrainskoho sportu [Features of development of investment projects for the development of modern material infrastructure of Ukrainian sports]. Stratehichne upravlinnya rozvitkom fizichnoi kulturi i sportu v konteksti 25-richchya nezalezhnosti Ukraini. Zb. materialiv IV Rehion. nauk.prakt. inter.-konf. z mizhnar. uchastyu. Kharkiv: KhDAFK. pp. 16-21. (in Ukrainian)

11. Nikolaenko V.V., Shevchenko A.Yu., Bulavinets, V.A. (2017) Sravnitelnyi analiz orhanizatsii detsko-yunosheskikh sorevnovaniy po futbolu v Ukraine i stranakh zapadnoy Evropy [Comparative analysis of the organization of youth football competitions in Ukraine and Western Europe]. Naukoviy chasopis NPU imeni MP Drahomanova. Seriya 15: Naukovo-pedahohichni problemi fizichnoi kulturi (fizichna kultura i sport). no. 6, pp. 44-48 (in Russian)

12. Pavelko A.V. (2009) Orhanizatsiyno-pravovi zasadi derzhavnoho upravlinnya sistemoyu bezpeki na futbolnikh zakhodakh [Organizational and legal principles of state management of the security system at football events]. Derzhavne budivnitstvo. no. 1. pp. 53-67. (in Ukrainian)

13. Petrushevskiy Ye. I. (2021) Rozvitok handbolu v Ukraini v umovakh hlobalizatsiyi sportu [Development of handball in Ukraine in the context of globalization of sports] ( $\mathrm{PhD}$ Thesis, 017). Kyiv, $226 \mathrm{p}$. (in Ukrainian)

14. Platonov V., Esentaev T. (2015) Orhanizatsionno-upravlencheskie modeli pidhotovki sportsmenov vysokoy kvalifikatsii v usloviyakh politizatsii i kommertsializatsii olimpiyskoho sporta [Organizational and managerial models of training highly qualified athletes in the context of politicization and commercialization of Olympic sports]. Nauka v olimpiyskom sporte. no. 2, pp. 19-26. (in Russian)

15. Putyatina H. (2015) Institutsiyne zabezpechennya uchasti hromadi v rozvitku sferi fizichnoi kulturi ta sportu [Institutional support for community participation in the development of physical culture and 
sports]. Molodizhniy naukoviy visnik Skhidnoyevrop. nats. un-tu imeni Lesi Ukrainki. Seriya: Fizichne vikhovannya $i$ sport. vol. 19, pp. 27-31. (in Ukrainian)

16. Sushko R.O. (2018) Teoretiko-metodichni osnovi rozvitku sportivnikh ihor v umovakh hlobalizatsiyi (na materiali basketbolu) [Theoretical and methodological bases of development of sports games in the conditions of globalization (on the material of basketball)] (PhD Thesis) Kyiv: NUFVSU, 43 p. (in Ukrainian)

17. Cherba V.M., Herasimova Ye.V. (2017) Stan ta perspektivi rozvitku sferi fizichnoi kulturi v Ukraini [Status and prospects of development of physical culture in Ukraine.]. Ekonomika ta derzhava. no. 7, pp. 70-75. (in Ukrainian)

18. Shevchuk I.V. (2015) Mekhanizmi derzhavnoho upravlinnya u sferi fizichnoi kulturi i sportu na rehionalnomu rivni [Mechanisms of public administration in the field of physical culture and sports at the regional level] (PhD Thesis). Kiyiv: Akademiya munitsipalnoho upravlinnya; 2015. 23 p. (in Ukrainian)

19. Shkrebtiy Yu. M. (2005) Stan ta napryami udoskonalennya sistemi fizichnoho vikhovannya molodi [The state and directions of improvement of the system of physical education of youth]. Sportivniy visnik Pridniprov'ya. no. 1, pp. 13-16. (in Ukrainian) 